\title{
Service-dominant strategic sourcing: value creation versus cost saving
}

\author{
Laleh Rafati, Geert Poels \\ Center for Service Intelligence \\ Faculty of Economics and Business Administration, Ghent University, \\ Tweekerkenstraat 2, 9000 Gent, Belgium \\ \{laleh.rafati, geert.poels\}@UGent.be
}

\begin{abstract}
The concept of strategic sourcing recognizes that procurement is not just a cost function, but supports the firm's effort to achieve its long-term objectives. Organizations more and more expect from their chief procurement officer (CPO) to develop long-term and short-term plans in procurement. Typically, however, procurement is driven by a tactical spend management sourcing process aimed at cost saving targets, which is not able to support organizations in achieving strategic objectives like innovation, value creation, sustainable competitive advantage and long-term partnerships. A paradigm shift from a tactical way of thinking about sourcing to a more strategic way of thinking is needed by focusing on value-driven targets. To help realize the new paradigm of value-driven management in sourcing, we designed a systemic view on strategic sourcing based on Service-Dominant Logic and (service) systems thinking. We used this systemic view to develop the conceptual basis of a new modeling and analysis language that helps organizations in exploring sourcing alternatives according to value-driven management.
\end{abstract}

Keywords: strategic sourcing, value-driven management, Service-Dominant Logic, capability sourcing.

\section{Introduction}

The growing importance of supply chain management has led to an increasing recognition of the strategic role of procurement [1]. Procurement has evolved from mere buying [2] and has recently been recognized as a critical driving force in the strategic management of supply chains [3]. Procurement is not just a cost function, but supports the firm's effort to achieve its long-term objectives [4]. Organizations more and more expect from their chief procurement officer (CPO) to develop longterm and short-term plans in procurement. Generating and measuring savings, safeguarding quality, ensuring delivery availability, enhancing value creation, fostering partnerships and innovation will remain the top priorities of CPOs in supply chain management for the next coming years [5]. Procurement is, however, driven by a tactical spend management process aimed at cost saving targets, which is not able to support organizations in achieving strategic objectives like innovation, value creation 
and long-term partnerships [6]. A paradigm shift from a tactical way of thinking about sourcing to a more strategic way of thinking is needed by focusing on value-driven targets. Cox [7], [8] introduced a strategic view on sourcing as value-driven management in which sourcing is a cross-functional process that is based on a deep understanding of an organization's value creation processes and what is needed for performing these processes. To help realize value-driven management, we designed a systemic view on strategic sourcing based on Service-Dominant Logic and (service) systems thinking. We used this systemic view to develop the conceptual basis of a new modeling and analysis language that helps organizations in exploring sourcing alternatives according to the new paradigm of value-driven management. Our research methodology was Design Science Research [9], which is the standard research methodology used in the Information Systems discipline for designing new artifacts that solve unsolved problems or improve upon existing solutions.

Section 2 defines strategic sourcing as a sub-process of procurement and analyzes current techniques of strategic sourcing, which focus strongly on cost saving targets. Section 3 characterizes strategic sourcing as value-driven management and subsequently elaborates on our research objectives. Section 4 introduces our systemic view of strategic sourcing by taking a service ecosystem perspective of an organization that is focused on value creation instead of cost savings. Section 5 defines a strategic sourcing conceptualization as the conceptual basis of a new modeling language that helps implementing strategic sourcing as value-driven management. Section 6 presents a proof of concept evaluation that demonstrates by means of a case study of IT outsourcing in a large university hospital how a modeldriven strategic sourcing approach based on our envisioned modeling language helps exploring strategic sourcing alternatives from a value-driven management perspective. Finally, section 7 concludes and outlines future research.

\section{Strategic sourcing as tactical spend management}

Strategic sourcing is traditionally seen as a sub-process of procurement as described in [4], [10] (Fig. 1). The procurement process starts with spend analysis and ends with payment and is composed of two distinct phases: sourcing and purchasing. The sourcing phase encompasses the source-to-contract (S2C) sub-process of procurement with three executive steps: 1) spend analysis to collect and analyze spend data and then identify potential opportunities for cost reduction; 2) strategic sourcing to select the most appropriate go-to market sourcing strategies and then selection and evaluation of suppliers in alignment with the strategic goals of the firm; and 3) contract management for controlling and tracking the formal and legal agreements with suppliers to fully exploit the value of the contract arrangements. The purchasing phase encompasses the purchase-to-pay (P2C) sub-process of procurement with three executive steps: 1) the purchase requisition; 2) the purchase order and order confirmation; 3 ) the delivery notification and invoice payment. 


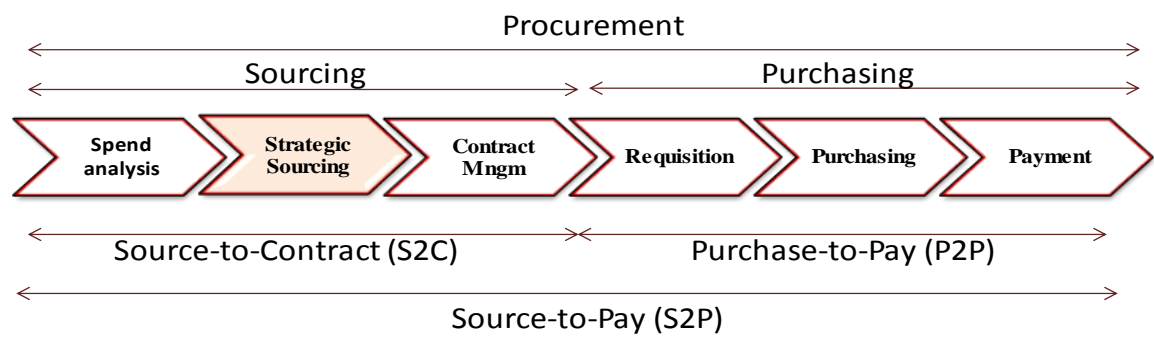

Fig. 1. Procurement process

The current techniques for strategic sourcing such as the Purchasing Category Portfolio of Kraljic [11] the Cox Power Portfolio model [12] and the purchasing chessboard approach [13] focus strongly on cost savings targets through applying spend analysis, supply market analyses and positioning techniques. They have been criticized for approaching strategic sourcing as a tactical spend management process rather than as a process of strategic importance to the organization [14], [15], [6]. Furthermore, the analyses do not consider all of the variables, which are required for assessing and evaluating the complexity of the supply market, the value of purchasing categories, the power of suppliers against buyers, and strategic sourcing alternatives [14], [15], [7]. In the next section, we present a new (strategic) way of thinking for strategic sourcing that caters for this shortcoming.

\section{Strategic sourcing as value-driven management}

According to the strategic thinking promoted by Cox [8], sourcing is a crossfunctional process that focuses on "leverage value for money trade-offs", not just "tactical cost savings". For value-driven management, the CPO should consider both the demand and supply bases for value creation to support the firm to achieve its strategic goals such as sustainable competitive advantage, enhancing value creation, increasing quality, mitigating risk, driving innovation and fostering long-term partnerships. Therefore, the CPO needs to manage the interactions between the organization's buyers, its suppliers and its internal and external customers by considering the resources, competencies and capabilities and relationships (e.g. customer-provider and buyer-supplier) of both the supply and demand side. Hence, requirements to realize-value driven management are a holistic view on the value chain and a more rigorous analysis of category value by considering both cost-down KPIs and value-driven KPIs. According to these requirements, we define our research objectives as Objective 1) Design a systemic view on strategic sourcing with emphasis on value creation to realize strategic sourcing as value-driven management. Objective 2) Develop a conceptual modeling language for the systemic exploration of strategic sourcing alternatives towards both cost saving and value creation targets. In the following section, we introduce our systemic view of strategic sourcing to realize value-driven management. 


\section{Service-Dominant Strategic Sourcing}

We believe that a systemic view on strategic sourcing that emphasizes the value creation by an organization will help realizing value-driven management. It is our position that the interpretation of complex emerging phenomena like value creation is greatly facilitated by a systems view that synthesizes both a reductionist perspective (i.e., analyzing elements and their relations) and a holistic perspective (i.e., being capable of observing the whole) [16]. We therefore propose a service ecosystem perspective for strategic sourcing as a systemic view that is based on the Viable Systems Approach (vSa) [17], [18] and Service-Dominant Logic (S-D Logic) [19]. The vSa is a systems theory that is increasingly getting attention in service research due to its contribution to understanding complex phenomena such as value cocreation. S-D Logic provides a framework for thinking more clearly about the service system and its role in competition [20] and survivability [19], which are two main objectives of strategic sourcing.

A viable system is defined as a system that survives, is both internally and externally balanced, and has mechanisms and opportunities to develop and adapt, and hence to become more and more efficient within its environment [21], [22]. A service ecosystem is then defined as a viable system of service systems connected (internally and externally) by mutual value creation interactions realized through service exchanges [23]. This ecosystem view is founded on S-D Logic, which is an important theoretical framework for the study of service systems [24], [25]. The S-D Logic views a service system as a dynamic value co-creation configuration of resources that is connected internally and externally to other service systems by value propositions through service exchanges [26]. While the traditional view on (tactical) sourcing is more a 'goods-dominant' worldview of suppliers and buyers as senders and receivers of goods (hence procurement's focus on realizing cost savings), the value-driven management view on (strategic) sourcing matches better the value co-creation interpretation of provider-customer relationships as in S-D Logic [20]. Therefore, a service ecosystem perspective for strategic sourcing introduces a way of thinking about strategic sourcing in terms of S-D Logic. We observe a clear similarity between S-D Logic concepts and strategic sourcing concepts (as value-driven management), as defined below in Table 1.

Table 1. S-D logic and strategic sourcing mapping of concepts

\begin{tabular}{|l|l|}
\hline \multicolumn{1}{|c|}{ S-D Logic Concepts } & \multicolumn{1}{|c|}{ Strategic Sourcing Concepts } \\
\hline $\begin{array}{l}\text { Operand Resources as usually tangible, static } \\
\text { and passive resources that must be acted on to } \\
\text { be beneficial, e.g., natural resources, goods, and } \\
\text { money [26], [27]. }\end{array}$ & $\begin{array}{l}\text { Resources as the firm's assets that require } \\
\text { action to make them valuable and beneficial } \\
\text { for the firm to sustain competitive advantage. } \\
\text { Strategic resources enable organizations to } \\
\text { sustain competitive advantage, if the } \\
\text { resources are Valuable, Rare, Inimitable, and } \\
\text { Non-substitutable (VRIN) [28], [29]. }\end{array}$ \\
\hline $\begin{array}{l}\text { Operant Resources as usually intangible, } \\
\text { dynamic and active resources that act upon other } \\
\text { resources to create benefits, e.g., knowledge, } \\
\text { skills [26], [27]. They are the essential } \\
\text { component of differentiation and the }\end{array}$ & $\begin{array}{l}\text { Competencies are the firm's specific } \\
\text { strengths that allow a company to gain } \\
\text { competitive advantage [31]. }\end{array}$ \\
\hline
\end{tabular}




\begin{tabular}{|c|c|}
\hline $\begin{array}{l}\text { fundamental source of competitive advantage } \\
\text { [30]. }\end{array}$ & \\
\hline $\begin{array}{l}\text { Service System as a configuration of resources } \\
\text { (at least one operant resource) that is capable of } \\
\text { providing benefit to other service systems and } \\
\text { itself [26]. }\end{array}$ & $\begin{array}{l}\text { Capability is a configuration of the firm's } \\
\text { resources and competencies that makes the } \\
\text { firm able to achieve and sustain competitive } \\
\text { advantage. Dynamic capabilities are the } \\
\text { firm's capacities and abilities to reconfigure } \\
\text { its resource base internally and externally to } \\
\text { achieve the sustainable competitive advantage } \\
\text { [32]. Dynamic capabilities act on operational } \\
\text { capabilities [33], [34]. }\end{array}$ \\
\hline $\begin{array}{l}\text { Service is the application of operant resources } \\
\text { for the benefit of another party [26]. Service is } \\
\text { the fundamental basis of value creation through } \\
\text { economic exchange. Competitive advantage is a } \\
\text { function of how one firm exchanges its services } \\
\text { to meet the needs of the customer relative to } \\
\text { how another firm exchanges its services [30]. } \\
\text { Surviving is a function of how the firm } \\
\text { exchanges its services to be able to survive and } \\
\text { thrive in its surrounding environment [35]. } \\
\text { Service is the primary source of competitive } \\
\text { advantage and survivability. However, "the only } \\
\text { true source of sustainable competitive advantage } \\
\text { and survivability is the operant resources that } \\
\text { make the service possible" [29]. }\end{array}$ & $\begin{array}{l}\text { Service is the application of competencies to } \\
\text { achieve competitive advantage or } \\
\text { survivability. Competitive advantage is the } \\
\text { ability to create more economic value than } \\
\text { competitors. It is a firm's profitability that is } \\
\text { greater than the average profitability for all } \\
\text { firms in its industry. Furthermore, sustained } \\
\text { competitive advantage is a firm maintaining } \\
\text { above average and superior profitability for a } \\
\text { number of years [31]. The primary objective } \\
\text { of strategic sourcing is to achieve a sustained } \\
\text { competitive advantage (in a commercial } \\
\text { domain) or survivability (in a non-commercial } \\
\text { domain), which in turn results in superior } \\
\text { profit or long-term viability. }\end{array}$ \\
\hline $\begin{array}{l}\text { Actors are engaged in the service exchanges as } \\
\text { value co-creators through actor-to-actor (A2A) } \\
\text { relations [31] at the micro, meso, and macro } \\
\text { level [36], [37]. They are essentially doing the } \\
\text { same thing: creating value for themselves and } \\
\text { others through resource integration [38]. An } \\
\text { actor can only offer a value proposition } \\
\text { concerning some services and cannot solely } \\
\text { create value for the beneficiary actor [39], [37]. }\end{array}$ & $\begin{array}{l}\text { Actors as buyers, suppliers, internal } \\
\text { customers and external customers are able to } \\
\text { create value through participation in a value } \\
\text { network with various relationships like } \\
\text { supplier-buyer relationship and customer- } \\
\text { provider relationship in both the demand and } \\
\text { supply sides of the value chain [20]. }\end{array}$ \\
\hline $\begin{array}{l}\text { Value is an increase in the viability } \\
\text { (survivability, well-being) of the system. Value } \\
\text { comes from the ability to act in a manner that is } \\
\text { beneficial to a party [40]. A value proposition } \\
\text { establishes connections and relationships among } \\
\text { actors [39], [37]. The process of co-creating } \\
\text { value is driven by value-in-use (value } \\
\text { actualization), but mediated and monitored by } \\
\text { value-in-exchange (value capturing) [35]. }\end{array}$ & $\begin{array}{l}\text { Perceived value is defined by customers, } \\
\text { based on their perceptions of the usefulness of } \\
\text { the product on offer. Exchange value is } \\
\text { realized when the product is sold. It is the } \\
\text { amount paid by the buyer to the producer for } \\
\text { the perceived value [41]. Strategic sourcing } \\
\text { derives from value co-creation, which in the } \\
\text { provider role serves as value proposition to } \\
\text { customers, in the supplier role serves as value } \\
\text { facilitation to customers, and in the customer } \\
\text { role serves as value actualization [20]. }\end{array}$ \\
\hline
\end{tabular}

Given these similarities, we define strategic sourcing as a strategic process for organizing and fine-tuning the focal firm's resources, competencies and capabilities internally and externally through A2A interactions with suppliers, buyers, internal and external customers, in order to achieve (sustainable) competitive advantage or 
survivability, which in turn results in value as superior profitability or long-term viability. In the next section, we use this systemic view of strategic sourcing to design a conceptualization as the foundation of a modeling language that can be used for the systemic exploration of strategic sourcing alternatives, in line with value-driven management.

\section{C.A.R.S - a conceptual modeling language for the systemic exploration of strategic sourcing alternatives}

Conceptual modeling is our proposed approach for exploring strategic sourcing alternatives and options from a service ecosystem perspective as described in the previous section. To create conceptual models that describe sourcing alternatives, a domain-specific modeling language [42] for strategic sourcing is needed. Such language is defined by a conceptualization of strategic sourcing. We introduce the C.A.R.S (Capability - Actor - Resource - Service) conceptualization as a new language for strategic sourcing modeling (Fig. 2). There is a clear mapping between the C.A.R.S concepts and the core concepts of S-D Logic as we apply them based on Table 1 to design a systemic view on strategic sourcing. The C.A.R.S concepts are defined as follows:

- Capability is 'What the actor Can do' for competitiveness and survivability. Capability as a configuration of C.A.R.S resources is the capacity and ability of an actor to create value through service exchange. The capability of an actor represents its potential long-term effects on the achievement of sourcing strategic objectives. Therefore, we define value-driven KPIs of strategic sourcing based on the capabilities of actors in the demand and supply side of the value chain.

- Actor is 'Who is the Resource Integrator' that provides service, proposes value, creates value and captures value. According to common sourcing relationships, suppliers offer value propositions to the focal firm; the focal firm (as a buyer) purchases service from suppliers; the focal firm (as a provider) delivers service to the customers; customers perceive and use value; and finally the focal firm captures value from both the demand and supply sides. All actors involved are co-creators of value in the value chain.

- The Resource base is 'What the actor Has' that provides the capability to create value. The resource base notion includes tangible and static resources (e.g., goods), as well as intangible and dynamic resources (e.g., competencies and skills). As in Table 1 we distinguish between assets (i.e., operand resources in SD Logic) and competencies (i.e., operant resources in S-D Logic). Resources are distributed across the market and can be configured to create capabilities.

- Service is 'What the actor Does' that is exchanged with other actors for competitiveness and survivability. Service is the application of resources to create value. We use this notion to illustrate the performance dimension of actors to achieve sourcing operational objectives (bottom-line results). Therefore, we define cost-down KPIs of strategic sourcing based on the performance of an actor like cost, quality, and delivery time. 
The next section presents a proof of concept evaluation of C.AR.S as the conceptual foundation of a modeling and analysis language for exploring strategic sourcing alternatives in line with value-driven management. We demonstrate the use of our model-driven strategic sourcing approach using an IT outsourcing case-study in the university hospital UZ Gent.

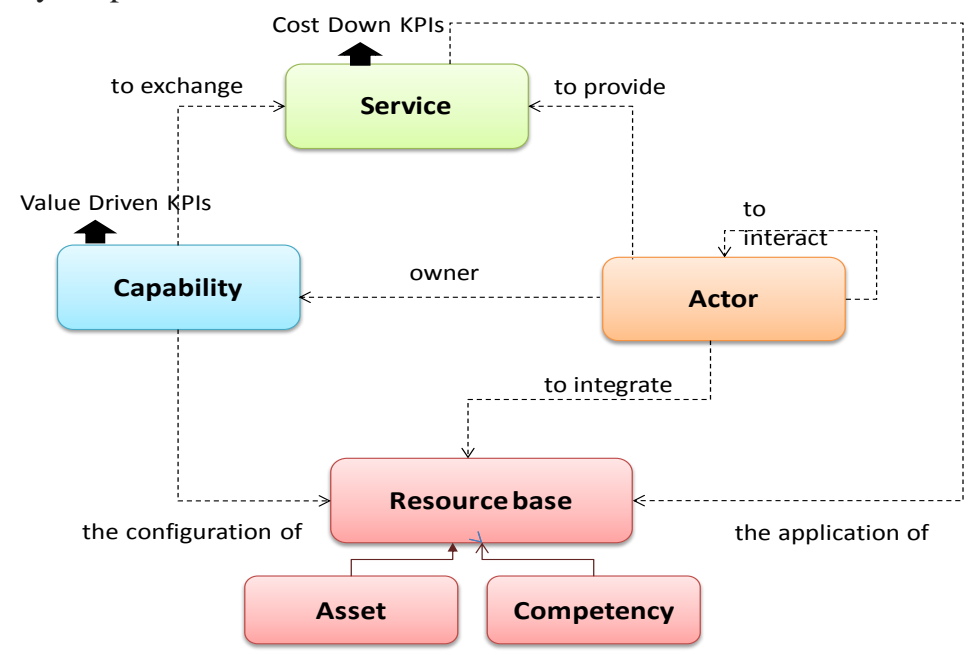

Fig. 2. C.A.R.S conceptualization and viewpoints

\section{A case-study of model-driven strategic sourcing}

The focus of model-driven strategic sourcing using C.A.R.S is on capability sourcing for value creation instead of identifying cost saving strategies for purchasing categories. Capabilities are the key to alignment and successful strategy execution. Capabilities exist across the value chain and in order to achieve profitability an organization must learn to manage capabilities that other parties in the value chain possess [43], [44], [45]. Firms must learn to govern a network of capabilities. Right sourcing allows having a sharper focus on the differentiating capabilities. On the other hand, incorrect sourcing decisions limit agility and increase costs [46].

We take an IT (out)sourcing case in the healthcare domain for demonstrating our model-based exploration of strategic sourcing alternatives and options. We describe this IT (out)sourcing scenario based on existing business/working papers about the healthcare IT contracts and agreements of UZ Gent [47]. Furthermore, we did a reality check with the chief information officer (CIO) of UZ Gent for a proof of concept evaluation of the proposed model-driven approach. In the following, we illustrate how a strategic sourcing decision maker like the CIO can apply our proposed model-driven method to explore strategies and recommendations for sourcing IT capabilities in the hospital. Model-driven strategic sourcing with C.A.R.S entails performing the three activities of strategic sourcing using techniques for capability sourcing, as explained below: 
Step 1: Determine capability positioning: This step aims at positioning C.A.R.S capabilities by considering both the demand and supply side of the value chain to find opportunities for cost saving and value creation. Inspired by Cox's criticality analysis [12], we introduce capability criticality analysis based on two dimensions of capabilities: the competitive advantage potential (i.e., commercial criticality) to create more economic value that results in superior profitability and the resource base availability (i.e., operational criticality) to achieve superior performance. The first dimension determines the competition degree of capabilities for sustainability and profitability such as sustainable competitive advantage (SCA), competitive advantage (CA), temporary competitive advantage (TCA) and parity competition (PC). The second dimension determines the criticality degree of the resource base configured by the analyzed capabilities, to achieve superior performance such as valuable resource base $(\mathrm{V})$, rare resource base $(\mathrm{R})$, inimitable resource base (I) and non-substitutable resource base $(\mathrm{N})$. The result of the capability criticality analysis is a 2 x 2 capability portfolio model with four categories: critical-strategic capability, strategic capability, critical-tactical capability and tactical capability.

Fig. 3 is a C.A.R.S model of UZ Gent that shows the exchange of two services for the benefit of internal and external customers of UZ Gent. These services are healthcare core services including clinical services and care services and healthcare supporting services including business administration services and ICT communication services. For UZ Gent, the value is the differentiation of healthcare core services and the low costs of healthcare supporting services. For exchanging these two services, UZ Gent requires four IT capabilities: healthcare core management (HCM), healthcare information management (HIM), hospital infrastructure management (HIN) and hospital business management (HBM). These hospital IT capabilities are based on various healthcare IT resources that provide the capacity to act, such as skills (e.g., clinical skills, business skills, ICT skills, technical skills, organizational skills), technologies (e.g., displays, monitors, workstations, projectors, video walls), software (e.g., image processing software and ERP software), systems (e.g., HIS, CIS, RIS, LIS, PACS, reporting system, decision support system and hospital-wide management information systems) and standards (e.g., Health Level-7 and DICOM).

Referring to the supply side of the value chain, Cerner, Xperthis, Agfa Healthcare, Barco, Infohos, Carestream Healthcare, GE Healthcare and Nexuz Healthcare are potential suppliers to provide healthcare core services. On the other hand, SAP, Oracle, Microsoft, EMC, Dimension Data, Realdolmen, HP, PHILIPS, Fujifilm, Dell and Siemens are potential suppliers to provide the healthcare supporting services. According to the hospital spend analysis, 40 percent of total cost (IT spending) has being spent on core services and $25 \%$ of total cost has being spent on supporting services. 


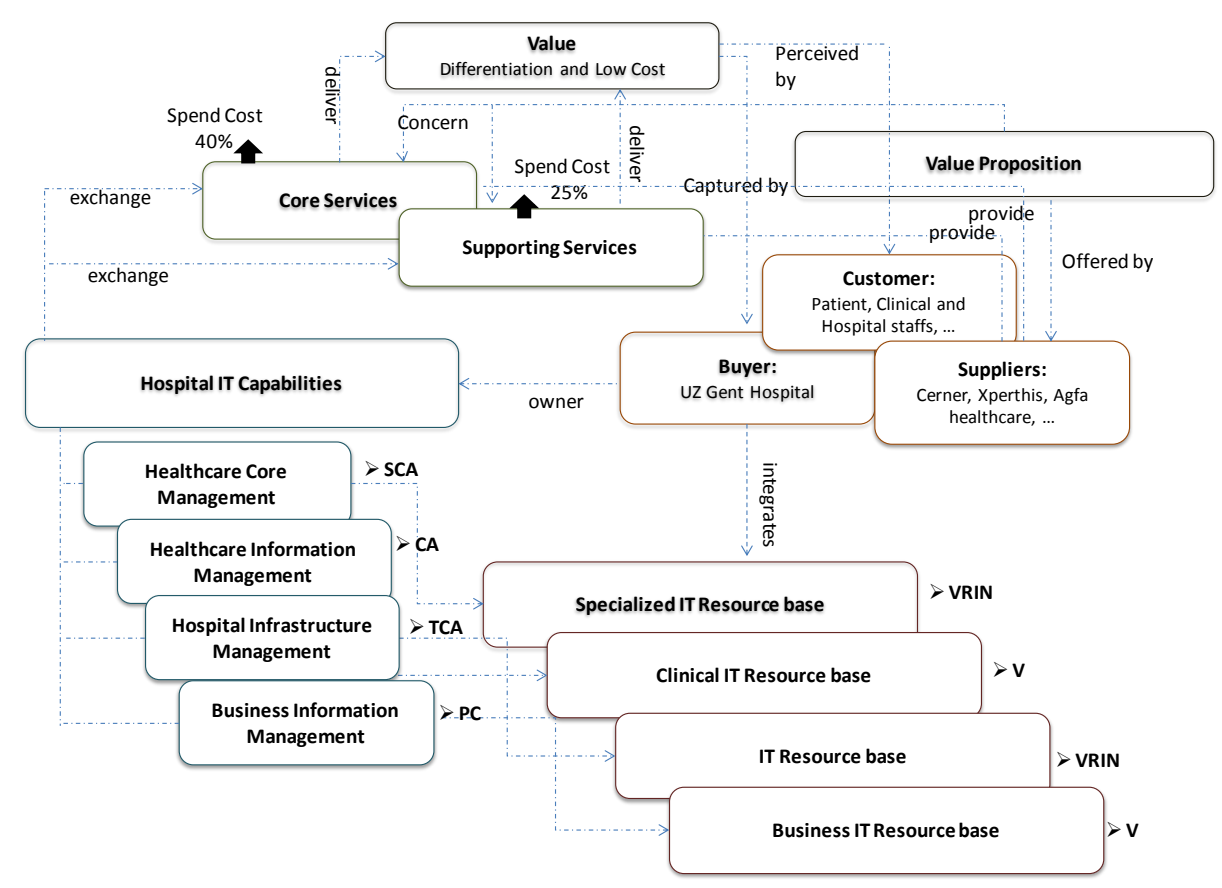

Fig. 3. C.A.R.S model of UZ Gent IT capabilities

The results of the capability criticality analysis have been added to Fig. 4 .

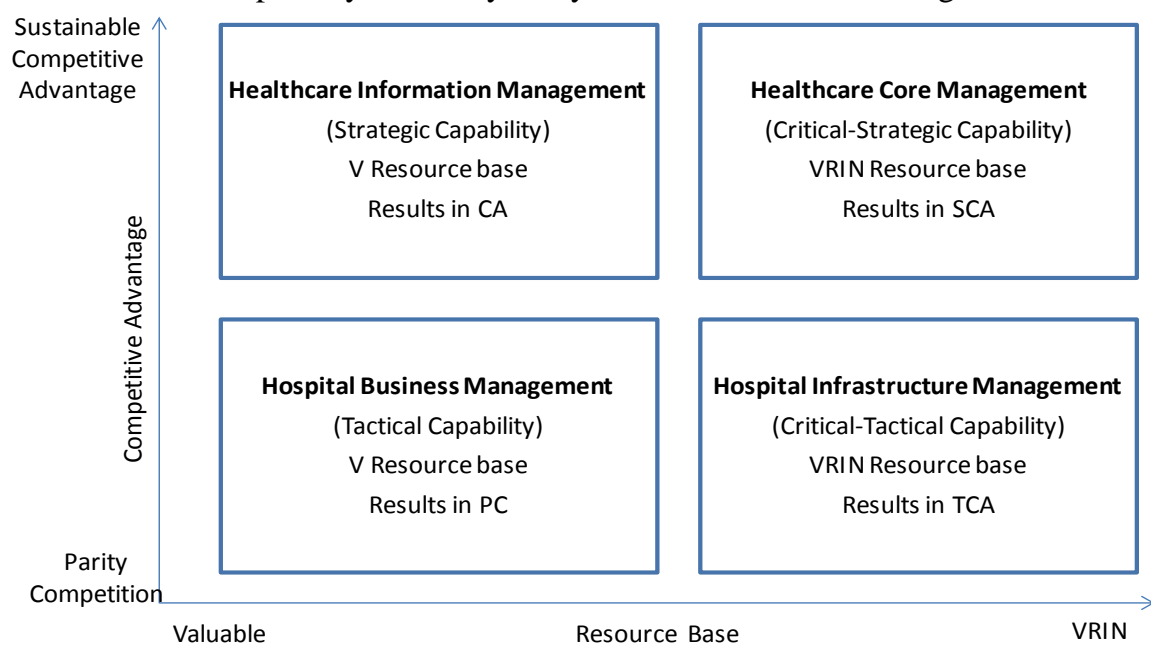

Fig. 4. Capability portfolio matrix of UZ Gent

Step 2: Determine (Buyer-Supplier) Dependency Positioning: This step aims at positioning the dependencies between buyers and suppliers for setting relationship strategies in the supply market. Our proposed approach classifies a buyer-supplier 
dependency into four categories (buyer dominance, supplier dominance, interdependence and independence) based on two dimensions, supplier power and buyer power, which are measured by 1) the essentiality and substitutability of the exchanged service [48] between buyer and supplier and 2) the capabilities, resources and competencies of both buyer and supplier to exchange service. Fig. 5 shows a C.A.R.S model that zooms in the HIS/RIS/PACS service that is provided by one of UZ Gent's suppliers, Agfa Healthcare, which is a specialized healthcare IT solution provider. This service is part of the healthcare core services that are exchanged by the HIM capability of UZ Gent.

The buyer-supplier dependency analysis showed that the HIS/RIS/PACS service is a common healthcare information system for UZ Gent with low-level criticality and low-level financial impact. On the other hand, this service is a core service of Agfa Healthcare with high-level criticality and high-level financial impact. There are more than five alternative suppliers (i.e., Xperthis, Barco, Infohos, Carestream Healthcare, GE Healthcare, Nexuz Healthcare and IBM Healthcare) to provide this exchanged service in the supply market with low-level switching costs. Moreover, there are less than three alternative buyers (i.e., one university hospital and two general hospitals) to request this exchanged service in the demand market resulting in a high-level searching cost. Therefore, the relationship between UZ Gent and Agfa Healthcare is positioned as a "buyer dominance" relationship.

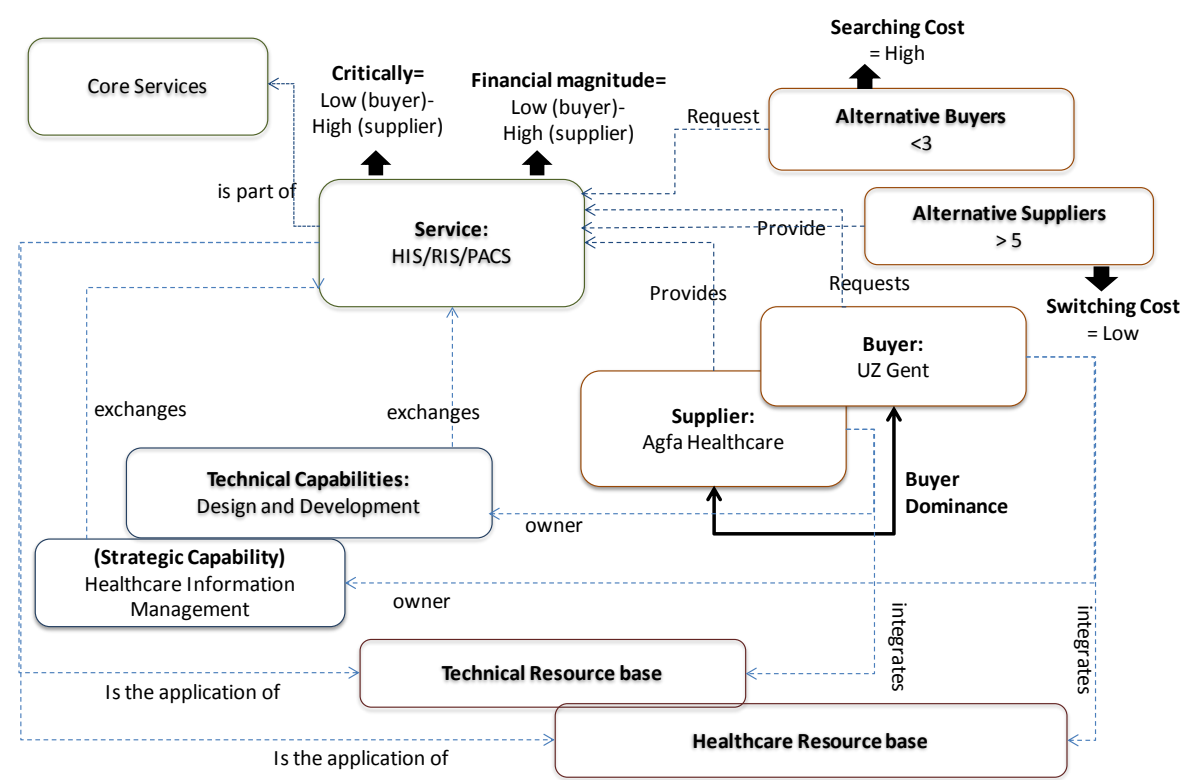

Fig. 5. C.A.R.S dependency model between UZ Gent and Agfa Healthcare

Fig. 6 shows the results of dependency analyses other UZ Gent suppliers. 


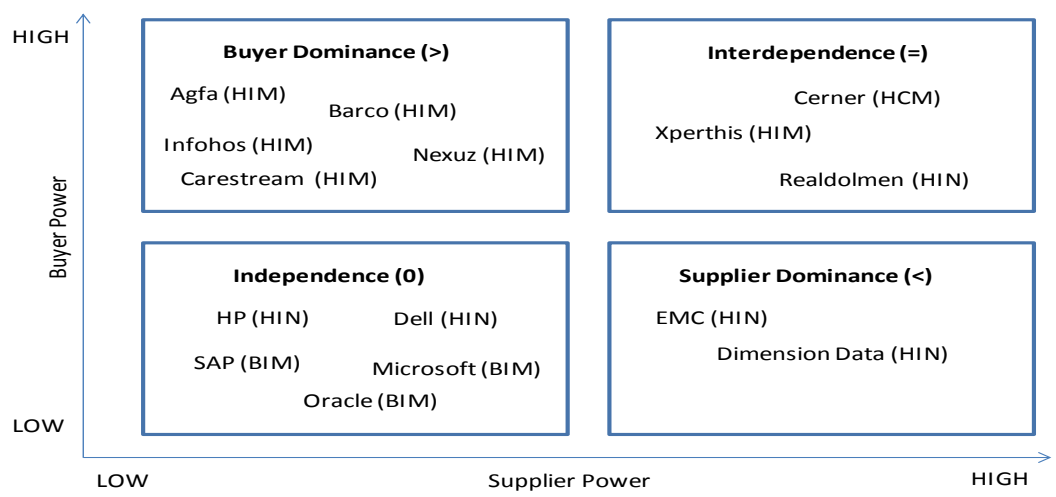

Fig. 6. UZ Gent - Suppliers dependency matrix

Step 3: Identify capability sourcing strategies: This last step aims at developing a portfolio for classifying capability sourcing and setting sourcing strategies. The technique proposed as Capability Sourcing Portfolio Analysis classifies capability sourcing into 16 categories based on the outcomes of the previous steps: the capability positioning (i.e., tactical capability, tactical-critical capability, strategic capability and strategic-critical capability) and (2) the buyer-supplier dependency positioning (i.e., interdependence, dependence, buyer dominance and supplier dominance). Capability sourcing portfolio analysis is inspired by the sourcing portfolio analysis of Cox [28], which is an existing approach to set strategies for categories of supply. This approach applies two leveraging principles for exploring sourcing options: 1) moving into an easy supply market (low complexity) and 2) understanding the current position and seek ways of exploiting or balancing the existing relationship [31], [12]. Fig. 7 shows the results of applying this analysis to the UZ Gent case.

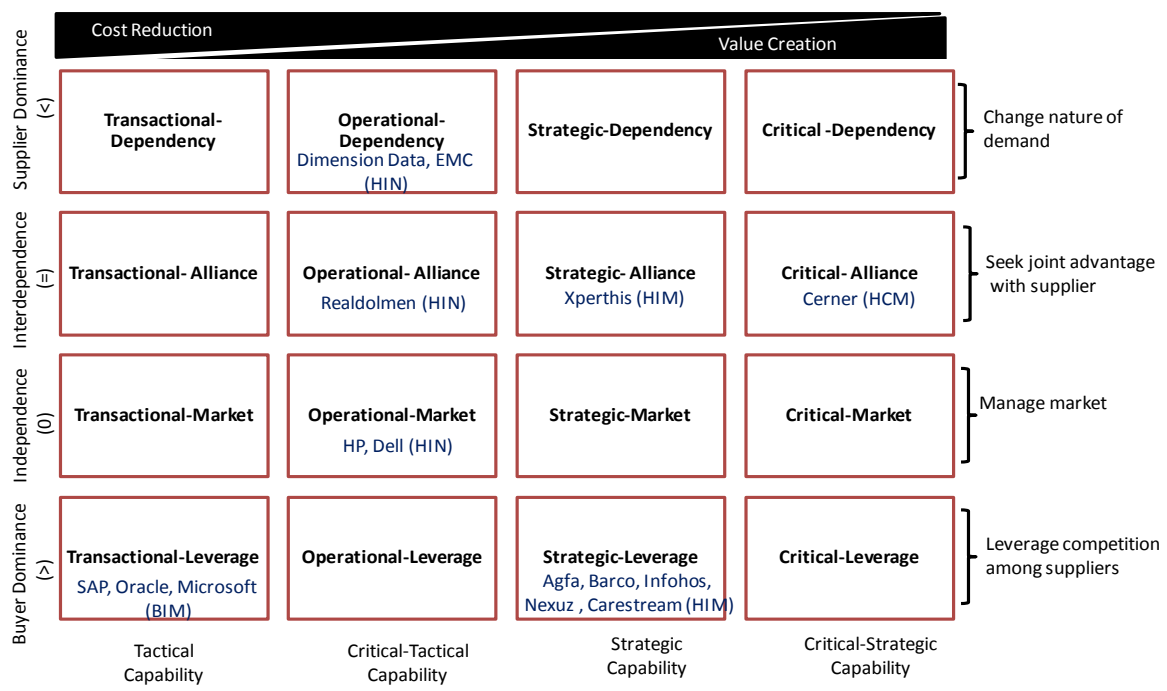

Fig. 7. UZ Gent capability sourcing portfolio 
For example, according to the capability sourcing portfolio analysis and its leveraging principles, for sourcing healthcare core management (HCM) as a criticalstrategic capability, the strategies and options available to UZ Gent are:

1. Develop an integrated health system in-house (insourcing) for selling to other hospitals (new customers) in the market (advantage: innovation; disadvantage: no cost saving) by improving the internal IT capabilities and internal IT resource base (according to leveraging principle1);

2. Moving into Market and Leverage positions (outsourcing) for cost reduction (disadvantage: no value creation), however, if there are no suppliers in the market and leverage positions, this is not viable option (according to leveraging principle1);

3. Maintain the strategic partnership with Cerner through long-term agreements for value creation such as differentiation (disadvantage: lock-in partnership) and reduce risk through master data management (according to leveraging principle2).

\section{Discussion and future research}

The CIO of UZ Gent believes that the current focus of strategic sourcing is on cost saving metrics (e.g., total cost of ownership, quality, and delivery time) rather than value creation factors (e.g., capabilities, competencies and resources). He realizes that the hospital really needs to create value by participation of its suppliers, internal and external customers to achieve sustainable competitive advantage. The model-driven strategic sourcing approach presented in this paper can support strategic sourcing decision makers like the CIO to achieve value creation targets (e.g., innovation and long-term partnerships) through providing a (IT) capability portfolio (extended by considering both the demand and supply sides) and a dependency portfolio (extended by considering all potential suppliers in the market) for strategic sourcing decisionmaking. We proposed a modeling and analysis language (C.A.R.S) for exploring strategic sourcing alternatives to support firms to achieve their strategic goals such as innovation (through finding new customers, services, products and partners), sustainable competitive advantage and long-term partnerships. Our future research includes 1) formalizing the C.A.R.S conceptualization and viewpoints as a capabilityoriented enterprise modeling language; 2) proposing a concrete syntax for the C.A.R.S meta-model; 3) providing modeling guidelines as way of working; and 4) analyzing the possible construction of KPIs by considering various techniques such as AHP, linear programming and fuzzy set theory for supporting strategic sourcing decision-making.

\section{References}

1. Anderson, P.H., Rask, M.: Supply chain management: new organizational practices for changing procurement realities. Journal of Purchasing and Supply Management, 9(2), pp. 83-95 (2003) 
2. Ellram, L.M., Carr, A.S.: Strategic purchasing: a history and review of the literature. International Journal of Physical Distribution and Materials Management, 30 (1), pp.9-19 (1994)

3. Chen, I.J., Paulraj, A., Lado, A.: Strategic purchasing, supply management and firm performance. Journal of Operations Management 22 (5), pp.505-523 (2004)

4. Weele, A.: Purchasing and Supply Chain Management. Analysis, Strategy, Planning and Practise, Cengage Learning EMEA, Hampshire (2010)

5. Berger, R.: The CPO's Agenda for 2014. Technical report, Aberdeen Group (2014)

6. Cox, A.: From Spend Management to Supply Management - Improving Category Management \& Strategic Sourcing. Technical report, IIAPS (2015)

7. Cox, A.: Sourcing Portfolio Analysis: Power Positioning Tools for Category Management \& Strategic Sourcing. Earlsgate Press (2014)

8. Cox, A., Ireland, P.: Value Flow Management: How to Create and Appropriate Value from KPI-Driven Companies and Supply Chains. Earlsgate Press (2015)

9. Peffers, K., Tuunanen, T., Rothenberger, M., Chatterjee, S.: A design science research methodology for information systems research. Journal of Management Information Systems, 24(3), pp.45-77 (2007)

10. Cox, A.: Sourcing portfolio analysis and power positioning: towards a "paradigm shift" in category management and strategic sourcing. Supply Chain Management: An International Journal, 20(6), pp.717-736 (2015)

11. Kraljic, P.: Purchasing must become supply management. Harvard Business Review, 61 (5), pp.109-117 (1983)

12. Cox, A.: Understanding Buyer and Supplier Power: A Framework for Procurement and Supply Competence. The Journal of Supply Chain Management, 37 (1), pp. 8-15 (2001)

13. Schuh, C., Kromoser, R., Strohmer, M. F., Pérez, R. R., Triplat, A.: The Purchasing Chessboard ${ }^{\mathrm{TM}}$, pp. 55-207, Springer Berlin Heidelberg (2009)

14. Cox, A.: Improving Procurement Competence. Technical report, IIAPS (2014)

15. Cox, A.: Power Positioning \& Sourcing Portfolio Analysis. Technical report, IIAPS (2015)

16. Von Bertalanffy, L.: The meaning of general system theory. General system theory: Foundations, development, applications, pp.30-53 (1972)

17. Ng, I., Parry, G., Maull, R., McFarlane, D.: Complex engineering service systems: a grand challenge. In Complex engineering service systems, pp. 439-454, Springer (2011)

18. Barile, S., Polese, F.: Smart service systems and viable service systems. In Service Science, 2(1-2), pp.21-40 (2010)

19. Vargo, S.L., Maglio, P.P., Akaka M.A.: On value and value co-creation: A service systems and service logic perspective. European management journal, 26(3), pp.145-152 (2008)

20. Eltantawy, R., Giunipero, L., Handfield, R.: Strategic Sourcing Management's Mindset: Strategic Sourcing Orientation and its Implications. International Journal of Physical Distribution and Logistics Management, 21 pages, 44(10), pp.768-795 (2014)

21. Beer, S.: Brain of the Firm. The Penguin Press, London (1972)

22. Beer, S.: The Viable System Model: Its Provenance, Development, Methodology and Pathology. The Journal of the Operational Research Society, 35(1), pp.7-25 (1984)

23. Vargo S.L., Lusch R.F.: From repeat patronage to value co-creation in service ecosystems: A transcending conceptualization of relationship. Journal of Business Market Management, 4(4), pp.169-179 (2010)

24. Maglio, P., Spohrer, J.: Fundamentals of service science. Journal of the Academy of Marketing Science, 36(1), pp.18-20 (2008)

25. Vargo, S.L., Lusch, R.F., Akaka, M.A.: Advancing service science with service-dominant logic: Clarifications and conceptual development. Handbook of Service Science (Springer, New York), pp.133-156 (2010) 
26. Vargo, S.L., Akaka, M.A.: Service-dominant logic as a foundation for service science: Clarifications. Service Science, 1(1), pp.32-41 (2009)

27. Poels, G.: The resource-service-system model for service science. International conference on Advances in conceptual modeling: applications and challenges. Springer Berlin Heidelberg, 6413. pp.117-126 (2010)

28. Barney, J.B: Firm resources and sustained competitive advantage. Journal of Management, 17 (1), pp.99-120 (1991)

29. Barney, J.B.: Gaining and sustaining competitive advantage. 2nd Ed. Upper Saddle River, NJ: Prentice Hall (2002)

30. Lusch, R.F., Stephen, L., Vargo, S.L., Matthew, O.: Competing through service: Insights from service-dominant logic. Journal of Retailing, 83(1), pp.2-18 (2007)

31. Hill, C., Jones, G.: Strategic Management: an integrated approach. Tenth edition, Cengage Learning (2012)

32. Helfat, C., Finkelstein, S., Mitchell, W., Peteraf, M., Singh, H., Teece, D., Winter, S.: Dynamic Capabilities: Understanding Strategic Change in Organizations. John Wiley \& Sons (2009)

33. Zollo, M., Winter, S.G.: Deliberate Learning and the Evolution of Dynamic Capabilities. Organization Science, 13(3), pp. 339-351 (2002)

34. Teece, D.: A dynamic capabilities-based entrepreneurial theory of the multinational enterprise. Journal of International Business Studies, 45(1), pp.8-37 (2014)

35. Vargo, S.L., Maglio, P.P., Akaka M.A.: On value and value co-creation: A service systems and service logic perspective. European management journal, 26(3), pp.145-152 (2008)

36. Akaka, M.A., Vargo, S.L., Lusch, R.F.: An exploration of networks in value cocreation: A service-ecosystems view. Review of Marketing Research, pp.13-50 (2012)

37. Vargo, S.L., Akaka, M.A.: Value Co-creation and Service Systems (Re)formation: A Service Ecosystems View, Service Science, 4(3), pp.207-217 (2012)

38. Wieland, H., Polese, F., Vargo, S.L, Lusch, R.F: Toward a service (eco) systems perspective on value creation. Wieland, H., Polese, F., Vargo, S., Lusch, pp.12-24 (2012)

39. Cardoso, J., Lopes, R., Poels, G: Service systems: concepts, modeling, and programming. Springer, pp. 1-91 (2014)

40. Vargo, S.L., Lusch, R.F: Service-dominant logic: Looking ahead. In Presentation at the Naples Forum on Service, pp. 14-17 (2011)

41. Bowman, C., Ambrosini, V.: Value Creation versus Value Capture: Towards a Coherent Definition of Value in Strategy. British Journal of Management, Vol. 11, pp.1-15 (2000)

42. Thalheim, B.: The science and art of conceptual modeling. In A. Hameurlain et al., editor, TLDKS VI, number 7600 in LNCS, pp.76-105, Springer, Heidelberg (2012)

43. Rafati, L.: Capability sourcing: a service-dominant logic view. Proceedings of the 8th Mediterranean Conference on Information Systems, 8 pages (2014)

44. Rafati, L., Poels, G.: Introducing service-oriented organizational structure for capability sourcing. In Exploring Services Science, pp. 82-91, Springer International Publishing, (2014)

45. Rafati, L., Poels, G.: Capability Sourcing Modeling: A high-level conceptualization based on Service-Dominant Logic. In Advanced Information Systems Engineering Workshops, pp. 77-87, Springer International Publishing (2014)

46. Loftin, R., Lync, R., Calhoun, J.: The Sourcing Canvas: A Strategic Approach to Sourcing Decisions. Technical report, Accelare (2011)

47. Sijnave, B.: The care information system of the future is VIRTUAL. Technica report in Presentation at 18de Colloquium Automatisering en zorgverlening, Affligem, Belgium (2014)

48. Jacobs, J.: Dependency and vulnerability: An exchange approach to the control of organizations. Administrative Sciences Quarterly, 19(1), pp.45-59 (1974) 